\title{
FACTORS AFFECTING THE OCCURRENCE OF TYPE 2 DIABETES MELLITUS AND DEPRESSION: A NEW EVIDENCE USING A PATH MODEL APPROACH
}

\author{
Esty Budiarti'), Didik Gunawan Tamtomo²), Rita Benya Adriani3) \\ 1)Masters Program in Public Health, Universitas Sebelas Maret \\ ${ }^{2)}$ Faculty of Medicine,Universitas Sebelas Maret \\ 3)Diploma Program in Speech Therapy, School of Health Politechnics Surakarta
}

\begin{abstract}
Background: Type 2 Diabetes Mellitus (Type 2DM) ranks third by global public health priority. Globally, the incidence of type 2 DM in 2014 was 442 million patients. Indonesia is one of 10 countries with high DM incidence. In 2014 the incidence was 10 million patients. Type $2 \mathrm{DM}$ is one of the most psychologically demanding chronic medical illness in adult. Comorbidity between diabetes and depression is quite common. However, limited data exists to document biopsychosocial predictors of depressive symptoms in Indonesian patients. This study aimed to examine the biopsychosocial factors affecting the occurence of type 2 DM and depression at Dr. Moewardi Hospital, Surakarta, using path analysis.

Subjects and Method: This was case control study conducted at Dr. Moewardi Hospital, Surakarta, from August to October 2017. Sample consisting of 100 patients type $2 \mathrm{DM}$ and 100 non DM patients were selected for this study by fixed disease sampling. The dependent variable was type $2 \mathrm{DM}$. The independent variables were body age, mass index, education level, occupation, stres, family income, comorbidity, activity, and family history of type $2 \mathrm{DM}$. The data were collected using medical record and questionnaire. The data were analyzed by path analysis.

Results: The biopsychosocial factors that directly affected the occurence of type $2 \mathrm{DM}$ and indirectly affected the occurrence of depression were highbody mass index $(b=2.66 ; 95 \% \mathrm{CI}=1.41$ to $3.91 ; \mathrm{p}<0.001)$, high income $(\mathrm{b}=-0.93 ; 95 \% \mathrm{CI}=-$ 1.90 to $0.045 ; \mathrm{p}=0.062)$, older age $(\mathrm{b}=2.88 ; 95 \% \mathrm{CI}=0.62$ to $5.15 ; \mathrm{p}=0.013)$, presence of DM family history $(\mathrm{b}=2.56 ; 95 \% \mathrm{CI}=1.45$ to $3.68 ; \mathrm{p}<0.001)$, and comorbidity ( $\mathrm{b}=3.25 ; 95 \% \mathrm{CI}=2.07$ to $4.43 ; \mathrm{p}<0.001)$. The occurrence of type 2 $\mathrm{DM}$ and depression was indirectly affected by physical activity, education level, physical activity, and occupation.

Conclusion: Higher body mass index, higher income, older age, presence of DM family history, and comorbidity, are the factors that increase the occurrence of type $2 \mathrm{DM}$ and depression.
\end{abstract}

Keywords: biopsychosocial factors, type 2 DM, depression, path analysis

\section{Correspondence:}

Esty Budiarti. Masters Program in Public Health, Universitas Sebelas Maret, Jl. Ir. Sutami 36 A, Surakarta 57126, Central Java.

Email: estybudiarti21@gmail.com. 